\title{
Anti-Sarcocystis neurona immunostaining associated with equine protozoal myeloencephalitis in Brazil
}

\author{
Imunomarcação de Sarcocystis neurona associada com um caso de mieloencefalite \\ protozoária eqüina no Brasil
}

Tatiane Alves da Paixão ${ }^{I}$ Isabela Oliveira de Paula RêgoI Renato de Lima Santos ${ }^{I *}$

\section{- NOTE -}

\section{ABSTRACT}

A retrospective study (1942 to 2005) of histopathological lesions included samples of central nervous system (SNC) from 203 animals in the Equidae family. A total of $42.4 \%$ of these samples had significant pathological changes, which were classified as inflammatory (62.8\%), degenerative (25.6\%), circulatory (10.5\%), and neoplasic $(1.1 \%)$ lesions. Immunohistochemistry anti-Sarcocystis neurona antigens was performed in all the cases with inflammatory changes (54), of which one of the case of encephalitis resulted positive to immunostaining. Although evidence of EPM (Equine Protozoal Myeloencephalitis) has been previously reported in Brazil, to the best of our knowledge, this is the first report in which characteristic EPM lesion was associated with anti-S. neurona immunostaining in Brazil.

Key words: equine, Sarcocystis neurona, myeloencephalitis, immunohistochemistry, Brazil.

\section{RESUMO}

Em um estudo retrospectivo (de 1942 a 2005), amostras do sistema nervoso central de 203 eqüídeos foram avaliadas para a presença de alterações histológicas. Dessas amostras, 42,4\% apresentaram alguma lesão histopatológica significativa, das quais foram classificadas como alterações inflamatórias (62,8\%), degenerativas $(25,6 \%)$, circulatórias (10,5\%) e neoplásicas (1,1\%). Fragmentos de SNC dos 54 animais com alterações inflamatórias foram avaliados para detecção de antígenos de Sarocystis neurona pela técnica de imunoistoquímica, que foi positiva em um caso de encefalite em eqüino. Embora haja registros de MPE no Brasil, este é o primeiro caso confirmado imunoistoquimicamente.

Palavras-chave: eqüino, Sarcocystis neurona, mieloencefalite, imunoistoquímica, Brasil.
Protozoal encephalitis is currently recognized as one of the most important causes of inflammation in the CNS of horse. Sarcocystis neurona, a coccidea protozoan (Apicomplexa, Sarcocystidea), parasites neurons, inflammatory cells and glial cells of CNS of horses. S. Neurona is the most common cause of EPM (DUBEY, 2001), a progressive neurological disease characterized by asymmetric ataxia associated with focal muscle atrophy (DUBEY et al., 2001a; SILVA et al., 2003). In addition to $S$. neurona, protozoa in the genus Neospora have also been identified as a cause of EPM (MARSH et al., 1996).

The diagnosis of EPM is largely based on the detection of antibodies against $\boldsymbol{S}$. neurona by western blot in the cerebrospinal fluid (CSF) (MACKAY et al., 2000; BACCARIN et al., 2001; SILVA et al., 2003). Nevertheless, western blot results must be interpreted with caution since a small number of seropositive horses develop clinical disease. The differential diagnosis should include other muscleskeletal and neurological disorders (DUBEY, 2001). Polymerase Chain Reaction (PCR) has been used to detect $\boldsymbol{S}$ neurona DNA in the CNS of live horses, although its sensitivity is relatively low since the parasite rarely is free in the CSF (MACKAY et al., 2000). The definitive diagnosis is achieved by histopathology associated with detection of the parasite in the CNS (SILVA et al, 2003), which usually requires immunohistochemistry (DUBEY, 2001). This communication reports the association of anti-Sarcocystis neurona

IDepartamento de Clínica e Cirurgia Veterinárias, Escola de Veterinária, Universidade Federal de Minas Gerais (UFMG). Av. Antonio Carlos, 6627, 31270-901, Belo Horizonte, MG, Brasil. E-mail: rsantos@vet.ufmg.br. * Autor para correspondência: 
immunostaining with a Brazilian case of encephalitis in equine.

A retrospective study (1942 to 2005) of histopathological lesions included samples of CNS from 187 horses and 16 mules. Animals were from fetal age to more than 30 years old. Histopathological changes were classified into inflammatory, degenerative, circulatory, and neoplasic lesions. The tissues from all of the 54 animals that had inflammatory changes in the CNS were processed for immunohistochemical detection of $\boldsymbol{S}$. neurona. In 34 of theses cases only fragments of the brain were available, whereas both the brain and spinal cord were available from the remaining 20 cases. Sections were stained by the streptavidin-biotin immunoperoxidase technique (LSAB, Dako, Carpinteria, USA) using a polyclonal antibody against $\boldsymbol{S}$. neurona, at 1:1000 diluition. The reaction was developed with $0.024 \%$ diaminobenzidin (DAB, DaKo, Carpinteria, USA). Sections of equine CNS known to contain $S$. neurona were used as positive controls.

Of the 203 cases reviewed, 42.4\% (86/203) had significant pathological changes, which were classified as inflammatory (62.8\%), degenerative (25.6\%), circulatory (10.5\%), and neoplasic (1.1\%). S. neurona antigens were detected in samples from a seven-year-old Thoroughbred mare admitted at the Veterinary Hospital in 2004. The mare was initially presented with a history of two weeks of ptosis of the lower lip, protrusion of the tongue, and anorexia. The mare was treated with corticosteroid (dexametasona), DMSO, vitamin B1 and fluid therapy. The clinical sings progressed with lateral decumbency due to paralysis of the limbs. The animal was euthanized due to poor prognosis. At necropsy, no significant gross changes were observed in the CNS.

Microscopically, a severe multifocal nonsuppurative encephalitis was observed predominantly in the gray matter of cerebrum, hypothalamus, and brain stem. There were areas of congestion, perivascular cuffs, multifocal gliose, and infiltration of inflammatory cells. Perivascular cuffs and inflammatory infiltrates were composed of lymphocytes, histiocytes, plasma cells, and occasional neutrophils. Multifocal astrocytosis and some spheroids indicative of axonal degeneration were observed. A mild multifocal lymphohistiocytic infiltrate was observed in the meninges. Numerous intra- and extracellular organisms were labeled by immunohistochemistry (Figure 1), which were rarely observed in hematoxylin and eosin stained sections (Figure 2). Multinucleated squizonts and bananashaped merozoites were observed within inflammatory cells, glial cells, vascular endothelium, and extracellularly in the neuropil.
The most frequent clinical signs observed in cases of EPM are asymmetric ataxia associated focal muscle atrophy due the usual involvement of spinal cord (SILVA et al. 2003). In this case, the mare had involvement of cerebrum and brain stem with no lesions in the spinal cord. Although the methodology employed here did not allow us systematically evaluate the clinical manifestation of the disease, the clinical sings were described as being characterized mostly by facial paralysis and ataxia, which are consistent with the histopathological localization of the inflammatory changes in the brain stem (MACKAY, et al., 2000). Although described as typical histopathological lesions in cases of EPM(MACKAY et al., 2000, DUBEY, 2001), hemorrhage and necrosis were not observed.

In this case, the organisms were relatively abundant in immunostained sections. It has been reported that anti-protozoal drugs can reduce while corticosteroids can increase the number of organisms in the CNS (MACKAY et al., 2000). Therefore, the history of treatment with corticosteroids in this case may have resulted in an increased number of organisms in the brain. In contrast, organisms were rarely seen in hematoxylin and eosin stained sections. $S$. neurona is observed in less than $50 \%$ of cases in hematoxylin and eosin stained sections (MACKAY et al., 2000). Therefore, immunohistochemistry is frequently required for the diagnosis (DUBEY, 2001).

Although in this case the lesions localized in the brain, the involvement of brain occurs in less than $10 \%$ of animals, with the spinal cord being the primary site for $\boldsymbol{S}$. neurona-induced lesions in the CNS (MACKAY et al., 2000; DUBEY, 2001; SILVA et al., 2003). Therefore, considering that several of the cases studied here did not include samples of the spinal cord, it is reasonable to assume that the frequency of $\boldsymbol{S}$. neurona-associated myeloencephalitis may have actually been underestimated in this retrospective study.

Clinical (BACCARIN et al., 2001), serological (DUBEY et al, 1999; Hoane et al 2006), and histopathological (BARROS et al., 1986; MASRI, 1992) evidences of EPM have been reported in Brazil. Furthermore, $\boldsymbol{S}$. neurona sporocysts were isolated from opossums (Didelphis albiventris) in Brazil (DUBEY et al., 2001b). However, to the best of our knowledge, this is the first reported in which a Brazilian case of EPM has been linked to anti-S. neurona immunostaing. Our finding, along with the previously reported evidences of $\boldsymbol{S}$. neurona infection in Brazil strongly indicates that EPM should always be considered in the differential diagnosis of equine neuropathies in Brazil. 


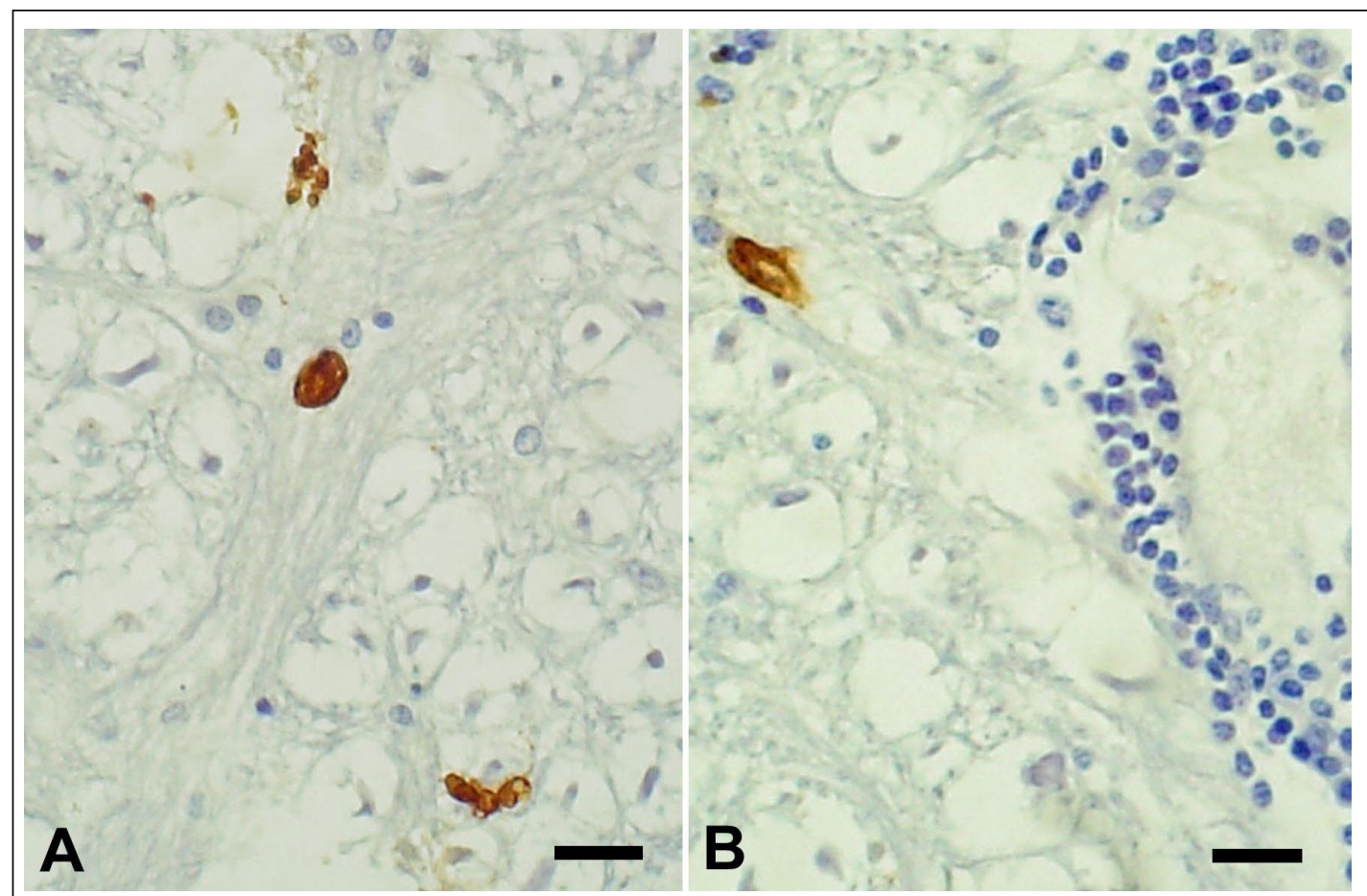

Figure 1 - Equine. Brain stem. Extra- and intracellular Sarcocystis neurona organisms (A), and adjacent perivascular lymphohistiocytic infiltrate (B). Streptavidin-biotin immunoperoxidase complex. Bar $=16 \mu \mathrm{m}$.

\section{ACKNOWLEDGEMENTS}

Authors are grateful to Dr. J. P. Dubey (USDA, ARS, ANRI) for providing the primary anti-S. neurona antibody, and to Dr. Corrie Brown (University of Georgia, Athens Georgia, USA) and the Veterinary Pathology Diagnostic Service at Texas A\&M University (College Station, Texas, USA) for providing paraffin-embedded control tissues.

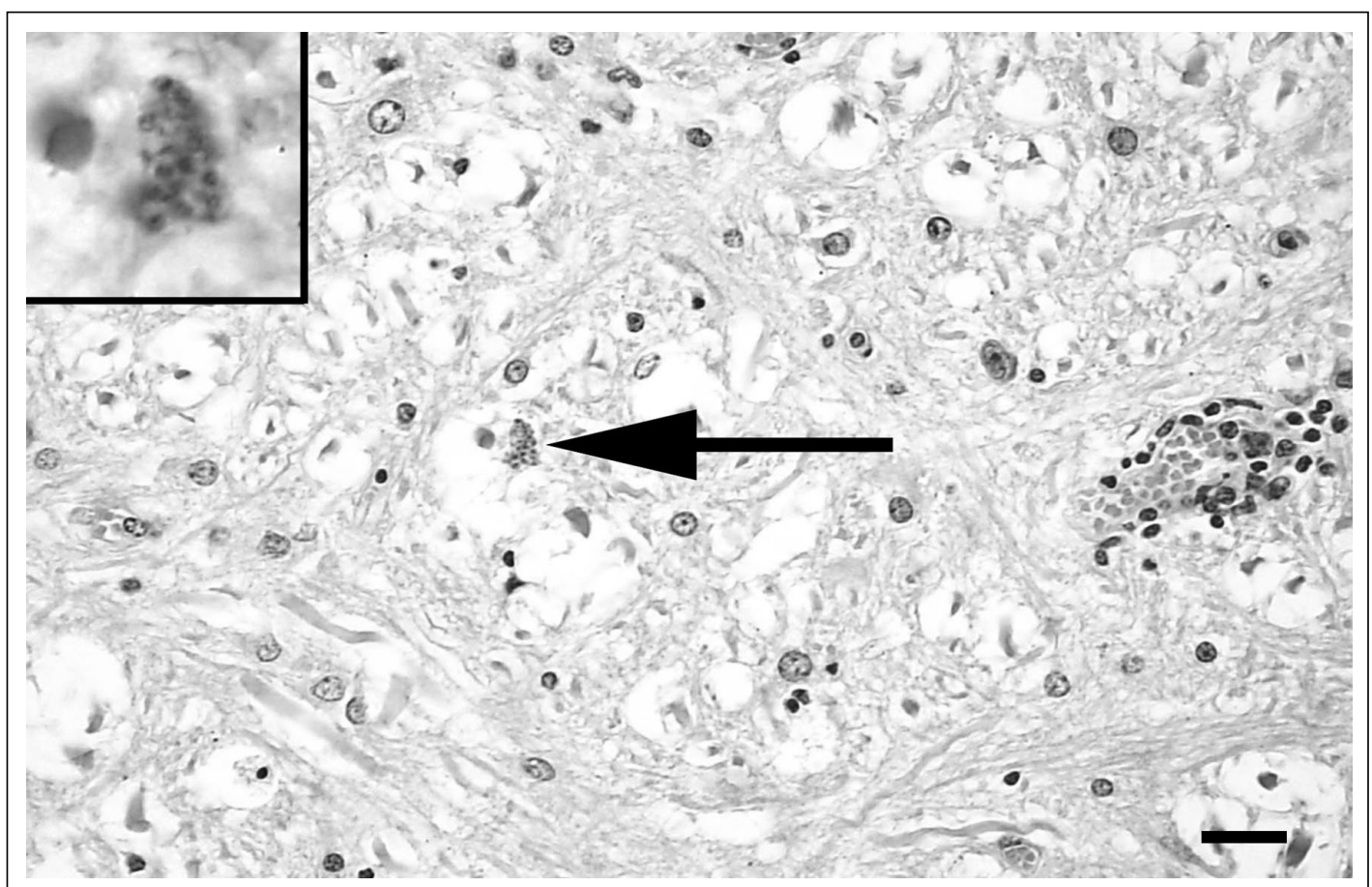

Figure 2 - Equine. Brain stem. Perivascular lymphohistiocytic infiltrate and Schizont of Sarcocystis neurona (arrow). Inset: detail of schizont. Hematoxylin and eosin stain. Bar $=24 \mu \mathrm{m}$.

Ciência Rural, v.37, n.6, nov-dez, 2007. 


\section{REFERENCES}

BACCARIN, R.Y.A. et al. Estudo da terapia e evolução clínica da mieloencefalite protozoária eqüina. Veterinária Notícias, v.7, p.79-85, 2001.

BARROS, C.S.L. et al. Mieloencefalite equina por protozoário. Pesquisa Veterinária Brasileira, v.6, p.45-49, 1986.

DUBEY, J.P. Recent developments in the biology of Sarcocystis neurona and equine protozoal myeloencephalitis (EPM). Journal Veterinary Parasitology, v.15, p.91-102, 2001.

DUBEY, J.P. et al. Sorologic prevalence of Sarcocystis neurona, Toxoplama gondii and Neospora caninum in horses in Brazil. Journal American Veterinary Medical Association, v.215, p.970-972, 1999.

DUBEY, J.P. et al. A review of Sarcocystis neurona and equine protozoal myeloencephalitis (EPM). Veterinary Parasitology, v.95, p.89-131, 2001a.
DUBEY, J.P. et al. First isolation of Sarcocystis neurona from the South American opossum, Didelphis albiventris, from Brazil. Veterinary Parasitology, v.95, p.295-304, 2001b.

HOANE et al. Prevalence of Sarcocystis neurona and Neospora spp. infection in horses from Brazil based on presence of serum antibodies to parasite surface antigen. Veterinary Parasitology, v.136, p.155-159, 2006.

MACKAY, R.J. et al. Equine protozoal myeloencephalitis. Veterinary Clinics of the North America: Equine Practice, v.16, p.405-425, 2000.

MARSH, A.E. et al. Neosporosis as a cause of equine protozoal myeloencephalitis. Journal American Veterinary Medical Association, v.209, p.1907-1913, 1996.

MASRI, M.D. Sarcocystis neurona-associated ataxia in horses in Brazil. Veterinary Parasitology, v.44, p.311-314, 1992.

SILVA, D.P.G. et al. Mieloencefalite protozoária eqüina: revisão de literatura. Revista Conselho Federal Medicina Veterinária, v.9, p.34-45, 2003. 